$\xi=-1$

\title{
Statistical Learning Game Application Assets for 5th Grade Elementary School Student
}

\author{
Jurike Moniaga $^{1 *}$, Yasinta Indrianti ${ }^{2,3}$, Sasmoko $^{2,4}$, Senly-Anthonius Halim ${ }^{1}$ \\ ${ }^{1}$ Computer Science Department, School of Computer Science, Bina Nusantara University \\ ${ }^{2}$ Research Interest Group in Educational Technology, Bina Nusantara University \\ ${ }^{3}$ Faculty of Social Podomoro University \\ ${ }^{4}$ Primary Teacher Education Department Faculty of Humanities \\ *Corresponding author E-mail: jurike@binus.edu
}

\begin{abstract}
Mathematics is often identified with difficult subjects, because most people find it difficult to understand mathematics. On the other hand, games can provoke interest in learning and can improve cognitive and motor skills. The research discusses the development of educational games to help learning mathematics in the theme of statistics in 5th grade elementary school student. This educational game is designed with research methods. The application is designed using UNITY to run the program, Paint tool SAI to draw characters, Dragon bones for animation, Adobe Photoshop to create sprite sheet. The results of this research were tried out to students of an elementary school in Jakarta through working on the questions in the game.
\end{abstract}

Keywords: Mathematics, Game Education, Statistics.

\section{Introduction}

As the development of the era, technology plays an important role in human life, especially digital technology. Now almost all the activities of the world rely on digital technology, especially computers and mobile phones (smartphones) [1]. Digital technology is very helpful to support human life in various fields, such as in industry, trade, food, politics, health, education, and so forth. Especially in the field of education, digital technology can help support the learning process of school children because digital technology has become a powerful new educational tool and interesting [2].

However, now days the desire of elementary school children in game play is higher than those children to learn. So that parents' view that games are not good for children. Therefore, we create educational game facilities to help learning of children especially in statistics lesson. Teachers have started trying to find approaches and new things in learning so many students do not get bored in traditional schooling, but until now there are still many who argue and agree if until now the school still get problems in terms of student motivation to learn [3]. Therefore, educational games can help students to be more motivated in learning. And also this educational game can increase the value and also the learning outcomes of many students especially mathematics [4].

The Federation of American Scientists also issued a report that the game as a medium offers a powerful new educational tool, because games are a tool that can be played by all people, especially children who are still in school. Game does not have a focus or a definite purpose because in the game there is a challenge that must be completed by the players to achieve success or finish the game [5]. Therefore the game can help children become more creative in thinking about success or through challenges in the game [6].
Because of this, many teachers are motivated to create new learning tools to support learning. Because when children play a game they look more creative in solving problems in the game, rather than solving a problem in learning in the classroom [7].

In terms of adult learning, both digital and traditional learning also have a great impact on adults in terms of education. Because by playing the game adults will be more creative and also have an impact to create a new way of life and also can develop learning for the future [8]. Computer-based games at this time have a high enthusiasm. And also many claims have been made about the benefits of learning with educational games compared to traditional learning approaches [9].

Applying learning to the application will have an impact on the quality of education. The quality of education depends on their ability to support children's involvement in this learning process. So that learning objectives can be fulfilled properly, must be considered in the design of animation, and also sound effects, so as not to be excessive when used by children [10]. In digital learning like today, sometimes it can have a negative impact on children, because children find it difficult to distinguish between games and educational games [11]. Therefore, for game-based learning should be considered the suitability of the game genre [12]. In educational games for children should also be considered the design of educational games, must be balanced between the fun and also the value of education, so that the educational game design is more effective [13]. To make a serious game design, there are difficulties that must be done, which is to bring together elements such as game design (prioritizing entertainment), simulation design (prioritizing loyalty), pedagogy, which prioritizes education [14].

Therefore, this educational game can help children to learn while playing because it will have a positive impact for the child. The game to be created is an educational game about mathematical material that is statistics. Which also comes with questions and 
answers so that children who play this game hopefully can understand statistics more effective with an interesting way. Teachers can also take advantage of this educational game to help the learning process to make it more interesting, fun and interactive.

\section{Literature review}

The theory of games is to study the interaction between decision making, players, and through mathematical models called games[15]. Games can be entertainment for all people [16]. But there are still many games that have difficulties that don't match the game players. Therefore, the designer gets a challenge to determine the difficulty in the game, so that the game is balanced with difficulties when played by the players [17].

Games also have positive benefits, there is a study linking sports to games, and the results obtained are combining video games with sports that make physical improvement better than traditional physical training [18]. Games have many benefits, especially in life, one of which is games can be our income, if we make the game can be bought and played by others [19].

Games define as a system in which players are involved in artificial conflicts, determined by rules, which results in measurable results [20]. Game-based education is defined as the type of game that has been determined by the learning outcomes [21]. In this study, statistical lessons were joined into a game, to be used as an educational game. Because combining games and lessons will be a very good and useful educational tool to improve learning [22].

The child's response will be very good if given an educational game, because games can help children to experiment more and develop themselves to be more creative, because the game can help children to know the world in their own way [23]. For educational games to be useful for educators, educators or teachers also require concepts for digital-based teaching. The concept has several approaches, namely using educational games, learning by making a game, and game design techniques in learning [24].

\section{Research methods}

The research method used in this research is explorative experimental which explores the design of an application game for elementary school class 5 . For the method of data collection is done by interviews and literature study. To create characters in the game the application used is an image using the paint tool Sai application, dragon bones for character animation, Photoshop to make sprite sheet.

\section{Design results}

The following is the design of the assets used in the game:

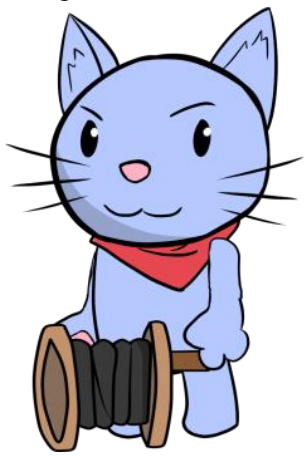

Picture 1. the main character in the game

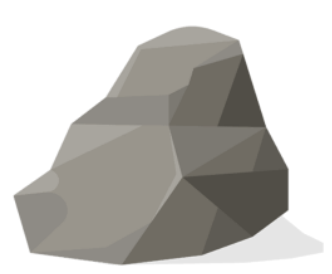

Picture 2. Small Rock (Obstacle)

Small Rock (Obstacle) includes an obstacle to prevent the player from taking coins. If the claw touch the rock, the claw will bounce up.

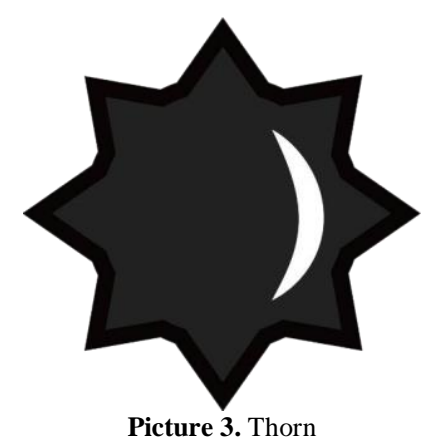

Thorn includes an obstacle to prevent the player from taking coins. If the claw touch the rock, the claw will bounce up.

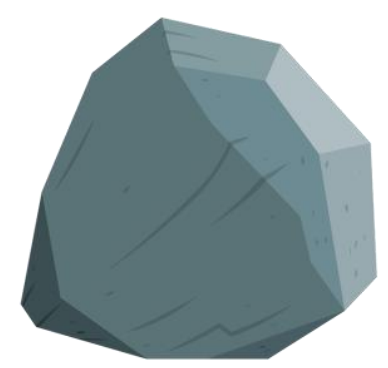

Picture 4. Big Rock

Big Rock (Obstacle) includes an obstacle to prevent the player from taking coins. If the claw touch the rock, the claw will bounce up.

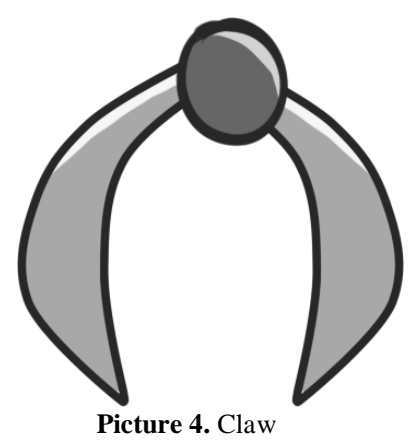

Claw is used to get points. 


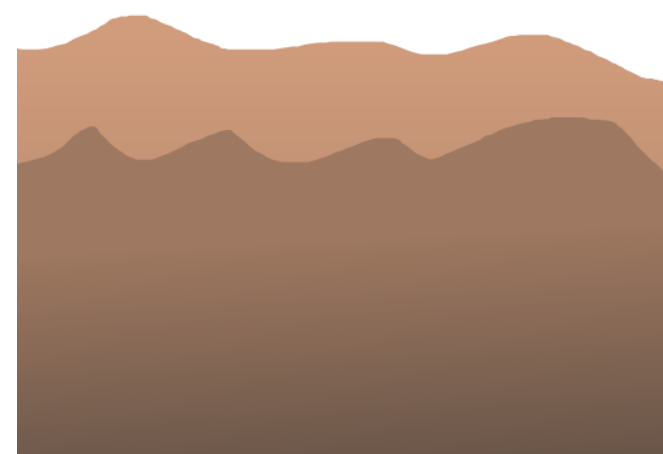

Picture 5. Game Background

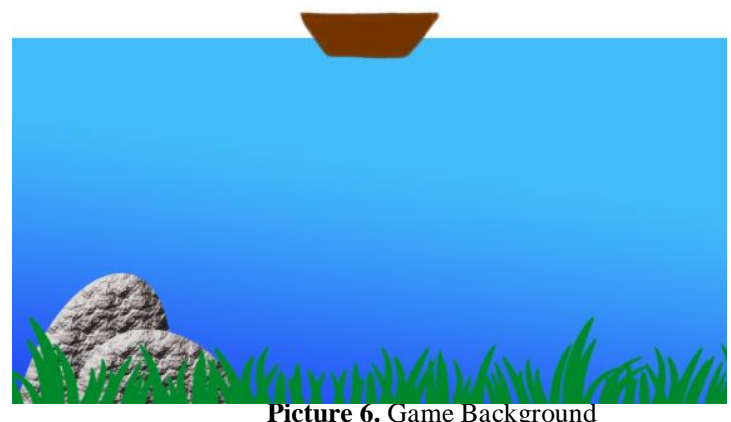

To get this background, players must buy in the shop provided in the game.

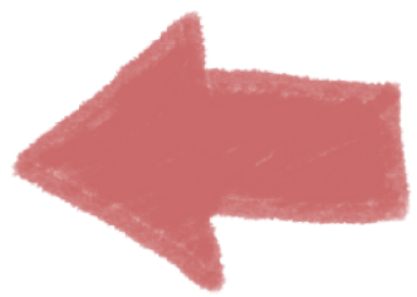

Picture 7. Back Button

Back button used to go back to main menu

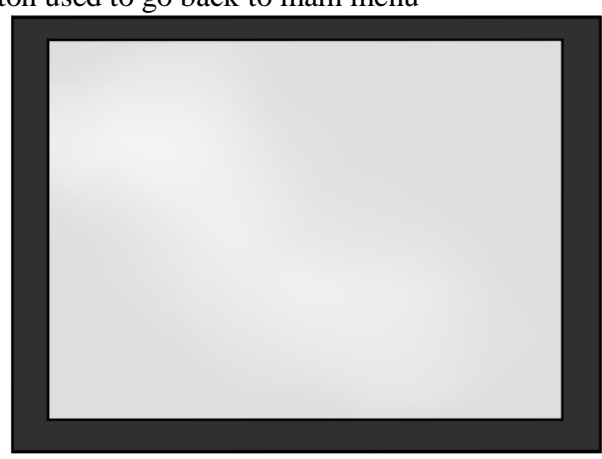

Picture 8. White board

White Board is used when the player is successful in capturing coins, a white board will appear with problems that must be done to get coins

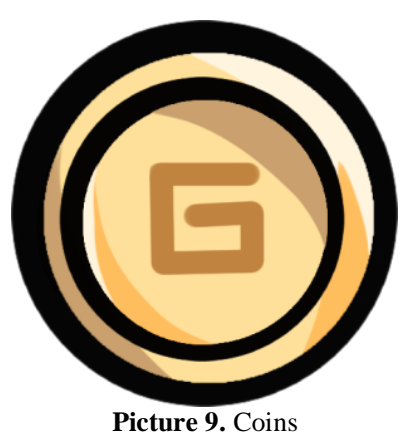

Coins is used to buy something at shops.

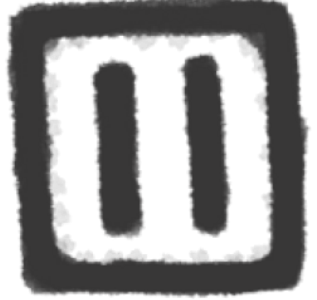

Picture 10. Pause Button

Pause Button is used to pause the game.

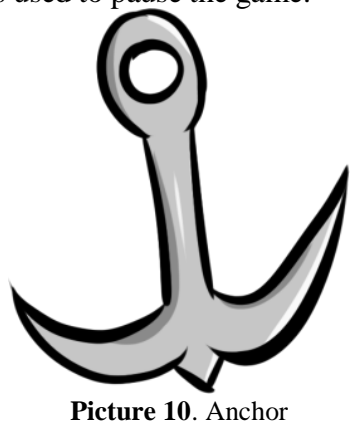

Anchor is used to get coins but must buy at the shop.

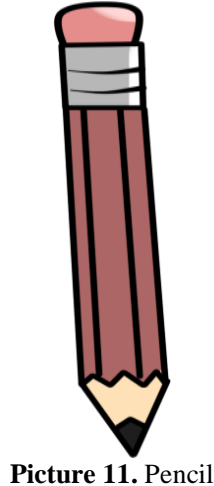

Pencil is used to get coins, but must buy at the shop

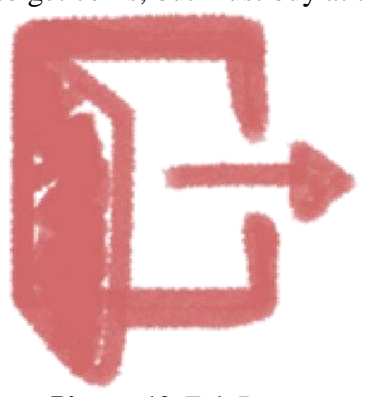

Picture 12. Exit Button

Exit Button is used to exit the game. 


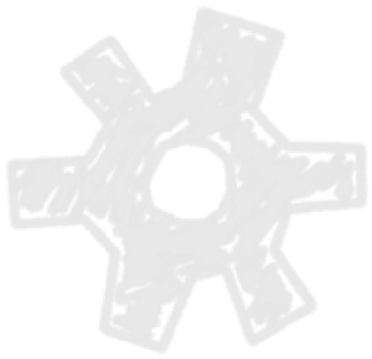

Pisture 13. Setting Button

The Settings button is used to set several things needed in the game.
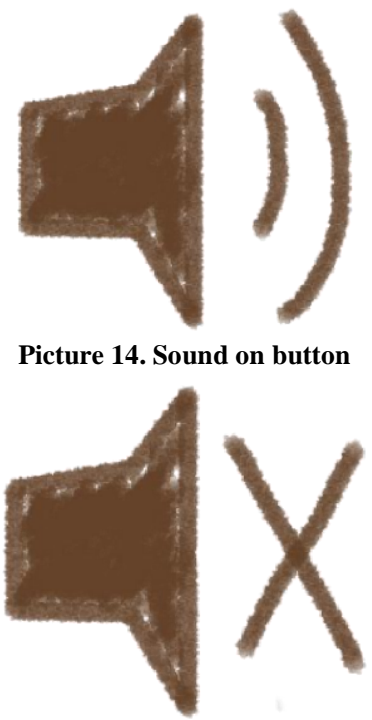

Picture 15. Sound off button

\section{Conclusion}

The educational game developed in this study is a game that contains math material for elementary school students, namely statistics. This game is equipped with multiple choice questions that allow students to play games and adjust material in a faster and more interesting way. The teacher can also use this educational game to help the teaching and learning process become more effective, fun, and interactive.

This game has considered several things in the development process, the first is the character and design of assets in the game. Character design and important assets in this educational game, for example, cat characters who are the main characters. Cat characters that can be used to attract students' attention so that they can increase their enthusiasm for statistical material lessons in this educational game.

Secondly, educational games must be balanced between fun and the value of education. If it is not balanced, it will have a negative impact on students. For example, educational content is more dominant, students will get bored quickly and are not interested in playing games. Conversely, if the contents of the game are more dominant, students do not get effective learning. Therefore, this game is recommended according to the current digital era context. The goal is to help students by utilizing technological advances to make it easier to understand mathematics.

\section{Acknowledgement}

This work is partially supported by Computer Science Department, School of Computer Science Bina Nusantara University and Research Interest Group in Educational Technology Binus University. The authors also gratefully acknowledge the helpful comments and suggestions of the reviewers, which have improved the presentation.

\section{References}

[1] Rideout VJ, MA, Foehr UG PhD \& Roberts DF PhD (2010), "Generation M2: Media in the Lives of 8 to 18 Year-Olds," Henry J. Kaiser Fam. Found 1-79.

[2] Selwyn N (2012), "Making sense of young people, education and digital technology: the role of sociological theory," Oxford Rev. Educ 38(1), 81-96.

[3] Dicheva D, Dichev C, Agre G \& Angelova G (2015), "Gamification in Education: A Systematic Mapping Study Gamification in Education: A Systematic Mapping Study," Educ. Technol. Soc 18, 75-88.

[4] Hsu CC \& Wang TI (2018), "Applying game mechanics and student-generated questions to an online puzzle-based game learning system to promote algorithmic thinking skills," Comput. Educ 121,73-88.

[5] Summary E (2014), "Digital Games, Design , and Learning: A Systematic Review and Meta-Analysis,"

[6] De Freitas S (2006), "Learning in Immersive worlds A review of game-based learning Prepared for the JISC e-Learning Programme," JISC eLearning Innov 3.3(14), 73.

[7] Anderson JL \& Barnett M (2013), "Learning Physics with Digital Game Simulations in Middle School Science," J. Sci. Educ. Technol 22(6), 914-926.

[8] Anderson B, Anderson M \& Taylor T (2009), "New Territories in Adult Education: Game-based Learning for Adult Learners," Adult Educ. Res. Conf 0-5,

[9] McLaren BM, Adams DM, Mayer RE \& Forlizzi J (2017), “A Computer-Based Game that Promotes Mathematics Learning More than a Conventional Approach," Int. J. Game-Based Learn 7(1), 36-56.

[10] Hirsh-Pasek K, Zosh JM, Golinkoff RM, Gray JH, Robb MR \& Kaufman J (2015), Putting Education in "Educational" Apps: Lessons From the Science of Learning 16(1).

[11] ter Vrugte $\mathrm{J}$, de Jong $\mathrm{T}$, Vandercruysse $\mathrm{S}$, Wouters $\mathrm{P}$, van Oostendorp H \& Elen J (2017), "Computer game-based mathematics education: Embedded faded worked examples facilitate knowledge acquisition," Learn. Instr (50),44-53.

[12] Peirce (2013), "Digital Game-based Learning for Early Childhood A State of the Art Report" 42.

[13] Moreno-Ger P, Burgos D, Martíne -Ortiz I, Sierra JL \& FernándezManjón B (2008), "Educational game design for online education," Comput. Human Behav 24(6), 2530-2540.

[14] Rooney P (2012), “A Theoretical Framework for Serious Game Design," Int. J. Game-Based Learn 2(4), 41-60.

[15] Grønbæk L, Lindroos M, Munro G \& Pintassilgo P (2018), "Game theory and fisheries," Fish. Res 203, 1-5.

[16] Boyle EA, Connolly TM, Hainey T \& Boyle JM (2012), "Engagement in digital entertainment games: A systematic review," Comput. Human Behav 28(3), 771-780.

[17] Costa Kohwalter T, de Azeredo Figueira FM, de Lima Serdeiro EA, da Silva Junior JR, Gresta Paulino Murta L \& Walter Gonzalez Clua E (2018), "Understanding game sessions through provenance," Entertain. Comput. 27,110-127.

[18] Sammut M, Sammut M \& Andrejevic P (2017), "The benefits of being a video gamer in laparoscopic surgery," Int. J. Surg 45, 4246.

[19] Balakrishnan J \& Griffiths MD (2018), "Loyalty towards online games, gaming addiction, and purchase intention towards online mobile in-game features," Comput. Human Behav 87, 238-246.

[20] Salen K \& Zimmerman E (2005), Game design and meaningful play. Handbook of computer game studies.

[21] Plass JL, Homer BD \& Kinzer CK (2015), "Foundations of GameBased Learning," Educ. Psychol 50(4), 258-283.

[22] Gee JP (2003), "What video games have to teach us about learning and literacy," Comput. Entertain 1(1), 20.

[23] Lucas FMM (2017), "The Game as an Early Childhood Learning Resource for Intercultural Education," Procedia - Soc. Behav. Sci 237, 908-913.

[24] Nousiainen T, Kangas M, Rikala J \& Vesisenaho M (2018), "Teacher competencies in game-based pedagogy," Teach. Teach. Educ 74, 85-97. 